\title{
Development of Islamic Education: The Multidisciplinary, Interdisciplinary and Transdisciplinary Approaches
}

\author{
Abd. Rahim Razaq ${ }^{1}$, *Dina Mardiana ${ }^{2}$, Umiarso ${ }^{3}$ \\ ${ }^{1}$ Universitas Muhammadiyah Makasar, Jl. Sultan Alauddin No 259 Makassar, Indonesia \\ ${ }^{2,3}$ Universitas Muhammadiyah Malang, Jl. Raya Tlogomas 246 Malang, Indonesia \\ *dinamardiana@umm.ac.id
}

\begin{abstract}
In the ideal level, Islamic education must touch on 3 (three) aspects. "Knowing" realm understanding value Islamic religion, "doing" realm practicing the values Islamic religion, "being" go through a period of life following values Islamic religion. However, the development of the 21st Century, which provides open access to all information from cyberspace, has not been fully implemented in the field of Islamic education so that it gives a challenge for the world of Islamic education in implementing the concept of "being" optimally in the process of learning. This article aims to describe and analyze the development of the Islamic education curriculum through 3 (three) approaches: multidisciplinary, interdisciplinary, and transdisciplinary. This article uses a qualitative approach to the type of literature study research. A literature study that is in line with the research theme leads this research to the conclusion. First, the Common Core State Standards (Kurikulum Inti) emerge as a form of balance standardization between the aspects of ideal learning and skills needs in the $21^{\text {st }}$-century. Second, the difference between multidisciplinary, interdisciplinary, and transdisciplinary approaches lies in the "starting point" of each approach. Multidisciplinary emerge as the form of concepts and skills desired by each discipline (explicitly), interdisciplinary in the form of shared concepts and skills, as long as a scientific discipline (implicitly) and transdisciplinary in the form of real reality in life where students being both subject and object in gaining that knowledge. Third, the similarity between multidisciplinary, interdisciplinary and transdisciplinary approaches lies to balance between accountability, relevance, and development of the $21^{\text {st }}$-century; all three are integral parts of the Core Curriculum; all three involve more than one scientific discipline in discussing a theme/issue and; all three have aspects of evaluation/assessment during the learning process.
\end{abstract}

Pada tataran idealnya, pendidikan Islam harus menyentuh pada 3 (tiga) aspek. Knowing dalam ranah mengetahui dan memahami ajaran agama Islam, doing dalam ranah mempraktikkan ajaran agama Islam, serta being yakni menjalani kehidupan sesuai dengan ajaran agama Islam. Namun, perkembangan abad ke-21 yang memberikan akses terbuka terhadap segala informasi dari dunia maya, belum diterapkan sepenuhnya di bidang pendidikan Islam sehingga memberikan tantangan bagi dunia pendidikan Islam dalam mengejawantahkan konsep being tersebut secara maksimal dalam proses pembelajaran. Artikel ini bertujuan untuk mendeskripsikan dan menganalisis pengembangan kurikulum pendidikan Islam melalui 3 
(tiga) pendekatan: pendekatan multidisipliner, interdisipliner dan transdisipliner. Pendekatan kualitatif dengan jenis penelitian studi pustaka digunakan dalam artikel ini. Kajian kepustakaan melalui literatur yang sesuai dengan tema riset, mengantar riset ini pada kesimpulan: 1) Kurikulum Inti (Common Core State Standards) lahir sebagai bentuk standarisasi keseimbangan antara aspek pembelajaran yang ideal dengan kebutuhan keterampilan di abad-21; 2) Perbedaan antara pendekatan multidisipliner, interdisipliner dan transdisipliner terletak pada starting point masing-masing pendekatan. Multidisipliner berupa konsep-konsep serta keterampilan-keterampilan yang diinginkan oleh masing-masing disiplin ilmu (secara tersurat), interdisipliner berupa konsep-konsep serta keterampilan-keterampilan bersama, sepanjang disiplin ilmu (secara tersirat) dan transdisipliner berupa realitas nyata dalam kehidupan dimana peserta didik menjadi subyek sekaligus obyek dalam memreoleh pengetahuan tersebut; 3) Persamaan antara pendekatan multidisipliner, interdisipliner dan transdisipliner terletak pada adanya upaya menyeimbangkan antara akuntabilitas, relevansi dan perkembangan abad 21; ketiganya bagian integral dari Kurikulum Inti; ketiganya melibatkan labih dari satu disiplin ilmu dalam membahas satu tema/isu dan; ketiganya memiliki aspek evaluasi/penilaian selama proses pembelajaran

\section{Keywords: Islamic Education, Multidisciplinary, Interdisciplinary, Transdisciplinary.}

Received: May 20, 2020; Revised: June 6, 2020; Accepted: June 9, 2020

\section{INTRODUCTION}

Today, the reality of the educational development in the $21^{\text {st }}$-century era has been able to create a big leap in the history of education, in which the source of knowledge is no longer limited to space and region (Nuur Abdulmajid \& Bayu Setiadi, 2015) (Muksin Wijaya, 2015). This massive change requires the readiness of the world of education to deal with and adapt to it. One of the concrete forms of the readiness of the world of Islamic education is through the efforts of progressive-visionary patterns of change from the curriculum level as a conceptual-theoretical guide (Ach.Sayyi, 2017); learning management (Muhamad Priyatna, 2017); (Umiarso, 2019); learning approach (Nur Khasanah, 2015); learning strategy (Vera Toktarova, 2015); (Siti Istiningsih \& Hasbullah, 2015) to aspects of teaching techniques in the practical-didactic realm (Dina Mardiana. \& Daniar Anggraini, 2019). Such efforts should be made so that the world of education can adjust itself (Peter Serdyukov, 2017), build their image, and to empower the students to be able to become adult human beings spiritually, emotionally and intellectually (R Mulyana, 2004) so that it can be a parameter of the success of the implementation of an education system (Uswatun Chasanah, 2017).

In the term of efforts to develop the educational curriculum area, nowadays many new theories have been emerged relating to the area of developing educational areas. Some of these theories are multidisciplinary, interdisciplinary, and transdisciplinary approaches. So, through efforts to develop Islamic education carried out with a multidisciplinary, interdisciplinary and transdisciplinary approach, it will bring progressiveness and improvement in the quality of Islamic education which has 
remained focused on the functional dimension, exceeding the social mental and spiritual dimensions (M. Mourad \& H.E Karanshawy, 2013); (Nata, 2009) as Deswita's research describes that it is a form of intelligence integration through the educational process (Deswita, 2010) which are more meaningful in the context the ultimate goal of Islamic education. This goal aimed to create humans in their capacity as educational subjects who understand God's nature (Amin Fauzi, 2017); (Mahfud, 2018).

\section{LITERATURE REVIEW}

\section{Conceptual Reorientation of the Development of Islamic Education}

Islam, as the religion of rahmatan li al-'Alamin, has guided in all aspects of human life, through the Qur'an and Hadith. Likewise, with science, the Qur'an provides the broadest opportunity for humans to develop their potential intellectual competence. From the first revelation (Syafiyyurrahman, 2015), for example, the exploration of science with the potential of human intelligence has been given an opportunity by Islam. Allah emphasizes the vastness of His knowledge that will never run (Surah alKahf verse 109) out to be explored and developed. So, it is clear enough if the efforts to develop the potential human competences in looking for knowledge both in the privatepartial and collective-institutional spheres should be continuously carried out and improved. One line that has broad access to the exploration of the potential competences is education, including Islamic education. To that is developed, the theses results of the knowledge that ultimately occupies the science hierarchy; every moment can review and renewable to develop sustainably and continuously.

In the ideal level, Islamic education must touch on 3 (three) aspects. "Knowing" realm understanding values Islamic religion, "doing" realm practicing the values of the Islamic religion, as well as "being," which according to go through a period of life under the values of the Islamic religion (Muhaimin, 2009). In the knowing and being needs, the progress and development of science and technology have created various variants of learning methodologies that fully support both domains of the learners themselves. Problems emerge when Islamic education is in contact with the third aspect, namely "being" directly related to the internalization of religious values. The process of "being" does not merely involve knowledge or practice - "knowing" and "doing"- in the brain and body of students, but more than that, it must be able to internalize the heart (qalb) of the students. The development and progress of science and technology seemed to provide its challenges in Islamic Education discourses to find solutions to the achievement of the "being" target in the teaching process.

Development age and technology in the $21^{\text {st }}$-century has become a fresh air for the development of aspects of "knowing" and "doing" as the previous description. The explosion of new knowledge in Islamic education and various benefits can obtain with the help of technology. Information and technology (IT) can provide open access to interactive material and information through networks (Fitriyadi, 2013). However, on the other side, without realizing it -whether to admit it or not- the development and progress of science and technology have not been based on conceptual frameworks that are friendly to humanity. Thus, it opens an opportunity for a destructive path due to a partial conceptual theory from the West (Azra, 2009). Islamic education focus on the cognitive aspects (knowing) and less attention to the aspects of the character (being) (Ali Maksum, 2011). 
Among several options, aspects of curriculum integration become one of the solutions that can propose to answer the challenges of science and technology in the realm of "being" that must include in Islamic education itself. The integrated curriculum can carry out with a multidisciplinary, interdisciplinary, and transdisciplinary approach.

The ultimate concept of science integration -which includes curriculum integration in it- in the Islamic education, emerge from the existence of an apparent dichotomy in Islamic education, as Muliawan elaborated on three aspects of the causes:

Factors of the historical development of Muslims since the Middle Ages ago (12501800 AD). Internal factors of Islamic education institutions that have not been able to make efforts to renew and develop. The field's classification factor in the study of science itself, which experienced so that inspiring a new scientific item in various disciplines (Jasa U Muliawan, 2005). With the appearance of the concept of science integration, there will be an integration between the style, character, and nature of knowledge, the unity of the material-physical dimension (knowing and doing), and the spiritual dimension (being).

Through the integration of Islamic education curricula - whether through multidisciplinary, interdisciplinary or transdisciplinary approaches - it is expected that there is an equivalence in the development of individual and applied aspects of education, so the learners (read: students) can develop in a balanced manner without any imbalance in one of their dimensions (Drake, 2013a).

\section{METHOD}

Based on the descriptions, this article focuses on conceptual reorientation in the development of Islamic education through 3 (three) approaches, namely multidisciplinary, interdisciplinary, and transdisciplinary. This article uses a qualitative approach to the type of literature study research through the focus of this research framework. A qualitative approach is used to understand the phenomena that occur namely the learning approach variant by multidisciplinary, interdisciplinary or transdisciplinary approaches. Hence, the data is collected by reviewing and analyzing the literature sources under the research theme. These sources came from the literature on the integrative curriculum in the context of Islamic education in books, journals, and others. Data analysis techniques use content analysis, which interprets as a method of analyzing the contents of messages contained in the literature.

\section{RESULT AND DISCUSSION}

\section{Integrative Curriculum: Philosophical Dimension}

As the narration writes before, the world of education must always be ready to adapt dynamically to dramatic changes that are increasingly fading into the $21^{\text {st }}$-century. When the education intersects with these changes, there will be at least three themes in force, namely accountability, relevance, and the context of the $21^{\text {st }}$-century itself (Drake, 2013b). Accountability (Wangid, Mustadi, Erviana, \& Arifin, 2014) and relevance (Wangid et al., 2014). Accountability and relevance that accompany the changes that occur must be able to be processed by the world of education in a balanced way. According to Drake's analysis, these efforts can make through standardization in the field of curriculum, which eventually emerges to a concept called 
the Common Core State Standards (Kurikulum Inti) (Drake, 2013c). An overview of the concept of the emerging of the Core Curriculum can see in the following chart:

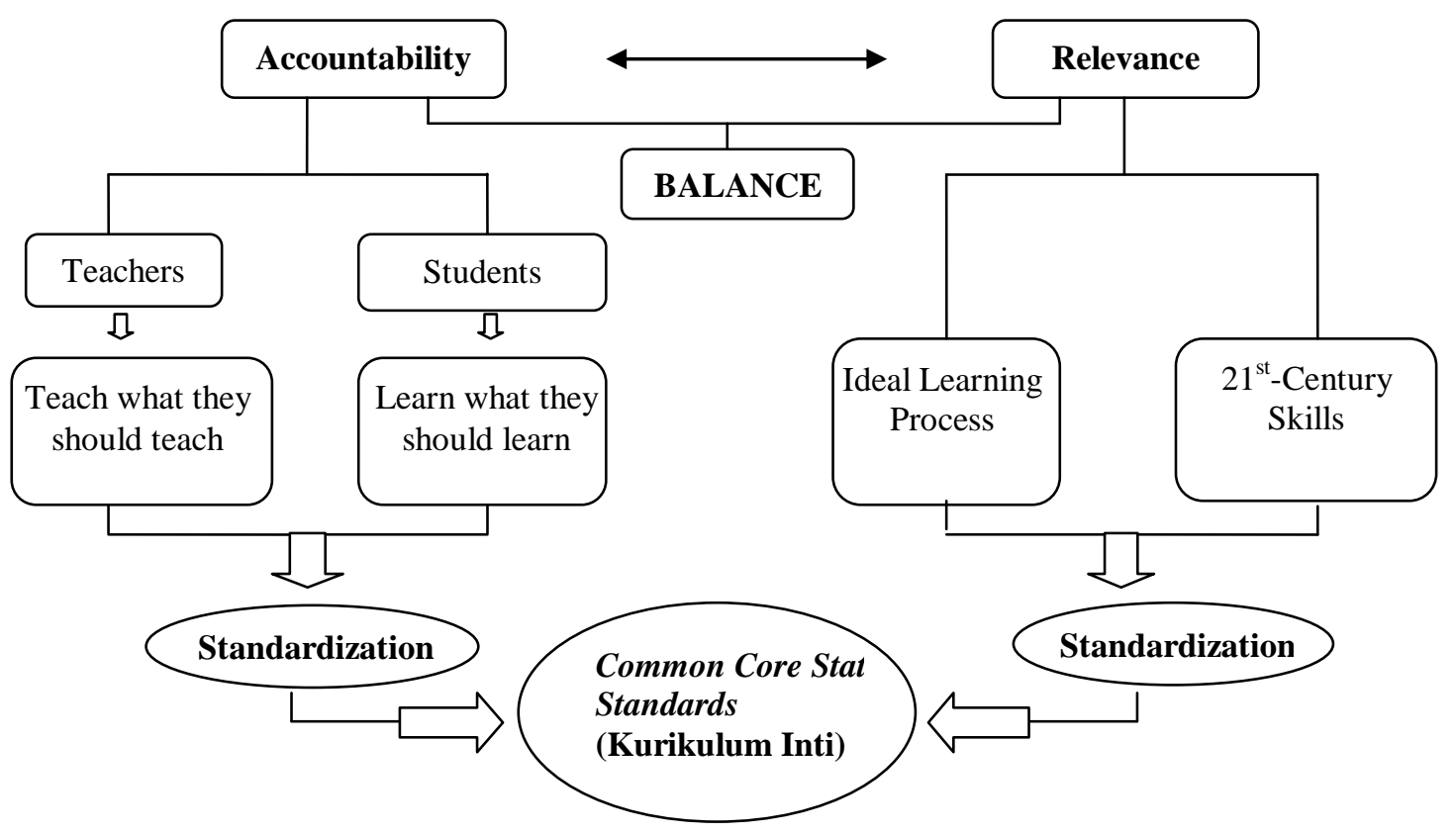

Figure 1. Creating a Core Curriculum through the concepts of Accountability and Relevance

Before discussing the development of Islamic education efforts through an integrative curriculum, it is essential to remember that there is a recognized level (hierarchy) of truth in Islam. It was citing Hitami's opinion that the hierarchy of truth is an absolute truth in the form of divine truth and human truth. This human truth is whose relativity is measured based on a scientific framework originating in the Broadest Knowledge (Hitami, 2004). Based on this understanding, the exploration in the management of Islamic education today has resulted in the discovery of curriculum integration through three approaches: multidisciplinary, interdisciplinary, and transdisciplinary.

\section{Multidisciplinary Approach}

Refer to the meaning of the word. Multidisciplinary is also called a parallel curriculum (Nata, 2009b), an approach that seeks to construct the concept of Islamic education using various Islamic religious disciplines. The scientific discipline includes history, philosophy, sociology, psychology, management, culture, information and technology (IT), and politics. Simply, Drake said that a multidisciplinary approach occurs in the condition of the same learning subject taught at the same time in different disciplines (Drake, 2013d). Based on the description, the researcher see the similarity of the two definitions put forward by Nata and Drake, that the multidisciplinary approach applies when there is a theme of the discussion that is global, then it is understood by using binoculars of knowledge from other diverse scientific disciplines which scientific group in one side is different from the others.

A simple practice that can facilitate understanding of this is the application of thematic learning at the elementary school level in Indonesia, which refers to the 2013 curriculum (K-13). In thematic learning, one theme is discussed by linking it to several subjects at once so that students gain new experiences meaningfully. Nurdyansyah's research, for example, found that through thematic learning with a social reconstruction model, it was able to provide students with an understanding of the dangers of 
corruption, while also training their sensitivity to phenomena that occur in the environment around students (Nurdyansyah, 2015). For example, in a broader scope, Islamic education can also be used as a central theme and then discussed and correlated with other disciplines. As Nata said in his research, Islamic education can be studied as a theme, then discussed, correlated, and analyzed from a variety of approaches, namely normative-parrenialism, historical, philosophical, psychological, sociological, management, information and technology (IT), and so on (Nata, 2009c).

One model (template) of planning in the context of a multidisciplinary approach was proposed by Drake, as shown below:

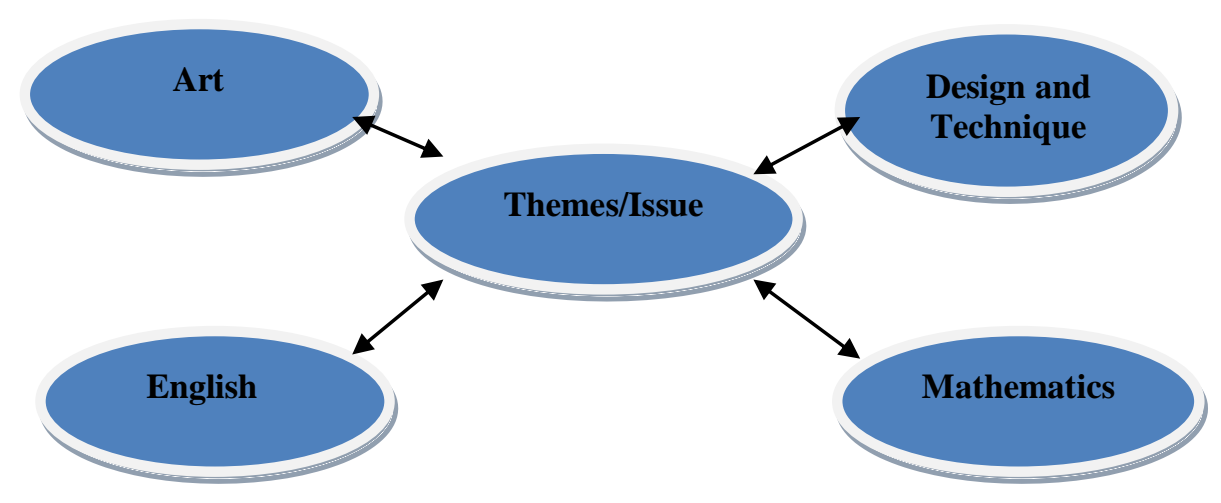

Figure 2: Multidisciplinary Organization Center (source: Drake, 2012)

\section{Interdisciplinary Approach}

In developing Islamic education with an interdisciplinary approach, Curriculums develop in areas around shared issues, themes, or problems where the emphasis of teaching is more focused on concepts or skills throughout the subject area and not located within it (Drake, 2013e). In other words, this approach creates a connection to the theme of the discussion by looking at everything based on more than one point of view. In the early era of its emergence in the late 1980s and early 1990s, ontologically, this interdisciplinary approach was oriented to the philosophy of John Dewey (1972). He followed the principles of constructivism (Drake, 2103f). It is base on the theory of constructivism, which is base on the acquisition of knowledge based on facts. The curriculum must also be established in the real world so that in the end, it will open the possibility of applying popular learning theories as multiple intelligence.

Whereas in terms of epistemology, this interdisciplinary approach implements by adjusting to the $21^{\text {st }}$-century -as Drake described- which has characteristics: Requires advanced $21^{\text {st }}$-century skills; Having a global perspective; Includes character education and leadership in performance; Includes collaborative learning, and learning do base on concepts (Drake, 2013g). 


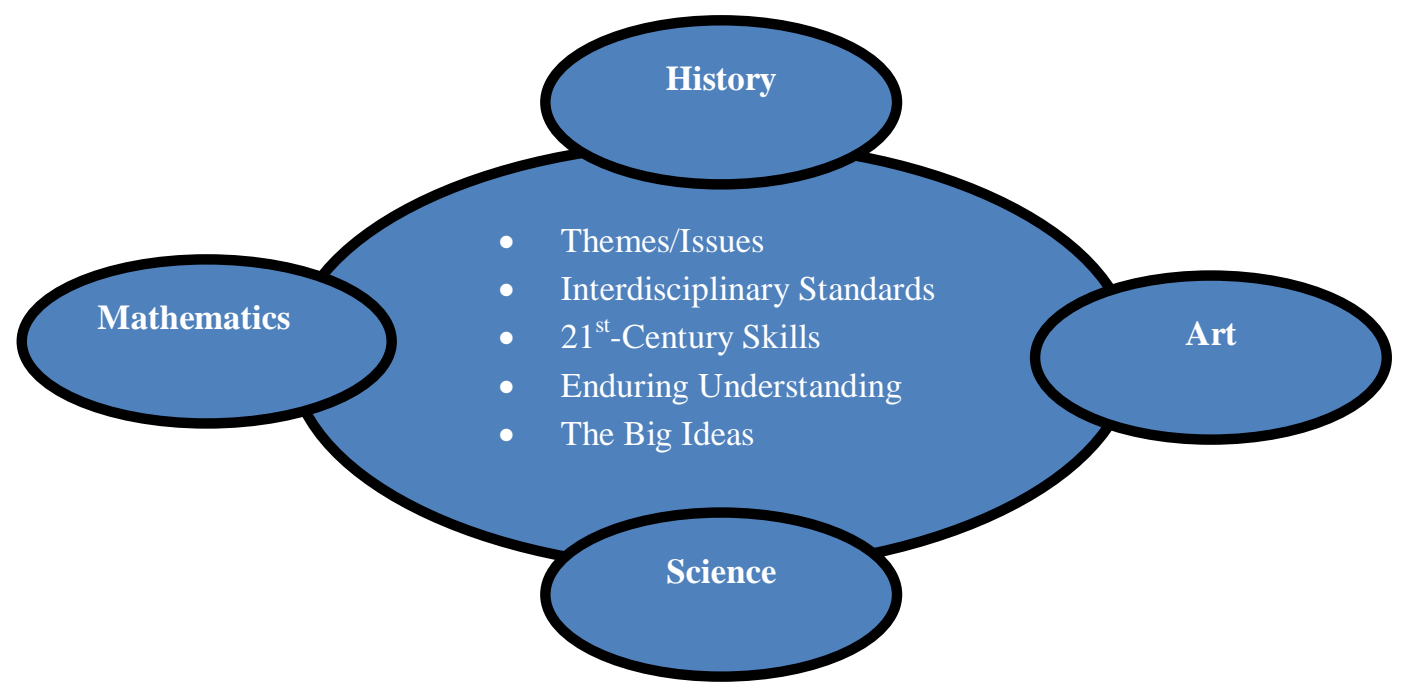

Figure 3: The Center of Interdisciplinary Organizations (source: Drake, 2012)

\section{Transdisciplinary Approach}

The curriculum applied to this transdisciplinary approach starts in the context of real life. On the dimension of the learning strategy, the transdisciplinary approach can see through the implementation of the Problem Based Learning (PBL) strategy which defines as a learning method that emphasizes the activeness and the role of students (student-centered) and supports the full aspects of developing lifelong learning skills (long-life education) (Prihanti, 2015).

The knowledge base that discusses through a transdisciplinary approach emphasizes the problems and questions emerged themselves. By exploring all of their curiosity about new knowledge, it hopes that with these learning experiences, a new theory will be raise that is different from before. Through experiential learning from experiments conducted in real terms, the students will be able to become humans who understand the meaning of learning and have aspects of caring. This kind of human is what came to be called the humanizing curriculum (Yamin, 2009).

To facilitate understanding of the transdisciplinary approach scheme, the following picture describes the design of the approach pattern:

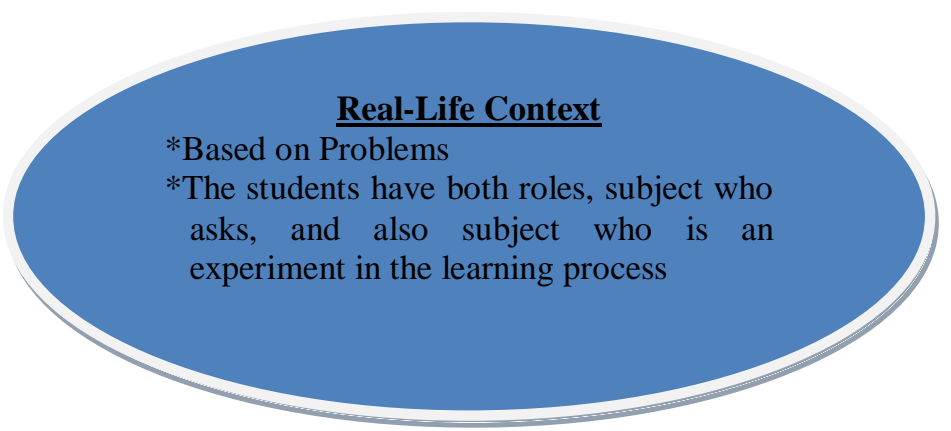

Figure 4: Templates of the Transdisciplinary Curriculum Planning 


\section{REFERENCES}

[1] Nuur Abdulmajid \& Bayu Setiadi. (2015). Pemanfaatan Social Web Environment in Menciptakan Student-Centered Learning dan Peningkatan Keterampilan Siswa pada Pembelajaran. Prosiding Seminar Nasional Universitas PGRI Yogyakarta, $1-6$.

[2] Muksin Wijaya. (2015). Pemanfaatan Tekhnologi Informasi dan Komunikasi dalam Pembelajaran. Economic: Jurnal Ekonomi Dan Hukum Islam, 5(2), 53-64.

[3] Ach.Sayyi. (2017). Modernisasi Kurikulum Pendidikan Islam dalam Perspektif Azyumardi Azra. Jurnal Tadris, 12(1), 20-39.

[4] Muhamad Priyatna. (2017). Manajemen Pembelajaran Program Kulliyatul Mu'allimin Al-Islamiyah (KMI) di Pondok Pesantren Modern Al-Ihsan Baleendah Bandung. Jurnal Edukasi Islami Jurnal Pendidikan Islam, 6(11), 22.

[5] Umiarso. (2019). The Multicultural Education in the Walisongo Modern Islamic Boarding School (Pesantren Modern). Episteme: Jurnal Pengembangan Ilmu Keislaman, 14(1), 47-72.

[6] Nur Khasanah. (2015). SETS (Science, Environmental, Technology and Society) sebagai pendekatan pembelajaran PAI modern pada Kurikulum 2013. Prosiding KPSDA, 1(1).

[7] Vera Toktarova. (2015). Design and Implementation of Mobile Learning Tools and Resources in the Modern Educational Environment of University. Review of European Studies, 7(8), 318-324.

[8] Siti Istiningsih \& Hasbullah. (2015). Blended Learning, Trend Strategi Pembelajaran Masa Depan. Jurnal Elemen, 1(1), 49-54.

[9] Dina Mardiana. \& Daniar Anggraini. (2019). The Effectiveness of Utilising WebLearning Media Towards Islamic Education Learning (PAI) Outcome in the Era of Industrial Revolution 4.0”. International Journal of Innovation, Creativity, and Change, 8(1), 80-96.

[10] Peter Serdyukov. (2017). Innovation in Education: What works, What does not, and What to do About It? Journal of Research in Innovative Teaching \& Learning, 10(1), 4-33.

[11] R Mulyana. (2004). Mengartikulasikan Pendidikan Nilai. Bandung: Alfabeta.

[12] Uswatun Chasanah. (2017). Ontologi, Epistemologi dan Aksiologi Pendidikan. Jurnal Tasyri', 24(1), 76-91.

[13] M. Mourad \& H.E Karanshawy. (2013). "Branding Islamic Studies: Exploratory Studi in The Middle East," Journal of Islamic Marketing. 4 (2), pp. 150-162. https://doi.org/10.1108/17590831311329287

[14] Deswita. (2010). Pendidikan Berbasis Kecerdasan Ruhaniah: Membentuk Insan Paripurna/Insan Kamil. Jurnal Ta'dib, 13(2), 186-196.

[15] Amin Fauzi. (2017). Integrasi Islamisasi Ilmu dalam Perspektif Pendidikan Islam. Jurnal Pendidikan Islam, 8(1), 1-17.

[16] Mahfud. (2018). Mengenal Ontologi, Epistemologi, Aksiologi dalam Pendidikan Islam. Cendekia: Jurnal Studi Keislaman, 4(1), 82-96. 
[17] Syafiyyurrahman. (2015). Shahih Tafsir Ibnu Katsir: Juz 'Amma. Jakarta: Pustaka Ibnu Katsir.

[18] Qur'an Surah Al-Kahf verse 109

[19] Muhaimin. (2009). Rekonstruksi Pendidikan Islam: Dari Paradigma Pengembangan, Manajemen Kelembagaan, Kurikulum hingga Strategi Pembelajaran. Jakarta: Raja Grafindo Persada.

[20] Fitriyadi, H. (2013). Integrasi Teknologi Informasi Komunikasi dalam Pendidikan: Potensi Manfaat, Masyarakat Berbasis Pengetahuan, Pendidikan Nilai, Strategi Implementasi dan Pengembangan Profesional. Jurnal Pendidikan Teknologi Dan Kejuruan, 21(3), 269-284.

[21] Azra, A. (2009). Mereka Bicara Pendidikan Islam: Sebuah Bunga Rampai. In Mereka Bicara Pendidikan Islam: Sebuah Bunga Rampai (p. 17). Jakarta: Raja Grafindo Persada.

[22] Ali Maksum. (2011). Plurarisme dan Multikulturalisme: Paradigma Baru Pendidikan Agama Islam di Indonesia. Malang: Aditya Media Publishing

[23] Jasa U Muliawan. (2005). Pendidikan Islam Integratif. Yogyakarta: Pustaka Pelajar

[24] Munzir Hitami. 2004. Mengonsep Kembali Pendidikan Islam. Yogyakarta: LKiS

[25] Drake, M. S. (2013). Menciptakan Kurikulum Terintegrasi yang Berbasis Standar. Jakarta: PT. Indeks.

[26] Wangid, M. N., Mustadi, A., Erviana, V. Y., \& Arifin, S. (2014). Kesiapan Guru Sd Dalam Pelaksanaan Pembelajaran Tematik-Integratif Pada Kurikulum 2013 Di Diy. Jurnal Prima Edukasia, 2(2), 175-182. https://doi.org/10.21831/jpe.v2i2.2717

[27] Wu Yan \& Catherine E. (2009). Principal Preparation and Training: a look at China and its Issues, International Journal of Educational Management. 23(1), pp. 51-64. https://doi.org/10.1108/09513540910926420

[28] Susan Drake. 2013. Menciptakan Kurikulum Terintegrasi yang Berbasis Standar. Jakarta: PT Indeks

[29] Munzir Hitami. 2004. Mengonsep Kembali Pendidikan Islam. Yogyakarta: LKiS

[30] Abuddin Nata. 2009. Ilmu Pendidikan Islam dengan Pendekatan Multidisipliner. Jakarta: RajaGrafindo Persada

[31] Susan Drake. 2013. Menciptakan Kurikulum Terintegrasi yang Berbasis Standar. Jakarta: PT Indeks

[32] Nurdyansyah. (2015). Model Social Reconstruction Sebagai Pendidikan AntiKorupsi Pada Pelajaran Tematik di Madrasah Ibtida'iyah Muhammadiyah 1 Pare. HALAQA: Jurnal Pendidikan Dan Keislaman, 14(1), 13-23.

[33] Nata, A. (2009). Ilmu Pendidikan Islam dengan Pendekatan Multidisipliner. Jakarta: PT. Indeks.

[34] John Dewey. 1972. My Pedagogic Creed, Article five, The School and Social Progress, in The Early Works (Ed. Boydston). USA: Southern Illinois University Press 
[35] Susan Drake. 2013. Menciptakan Kurikulum Terintegrasi yang Berbasis Standar. Jakarta: PT Indeks

[36] Prihanti, G. S. (2015). Strategi Belajar. Malang: UMM Press.

[37] Yamin, M. (2009). Manajemen Mutu Kurikulum Pendidikan. Yogyakarta: Diva Press. 